\title{
Inhibition of Bio corrosion of steel coupon by sulphate reducing bacteria and Iron oxidizing bacteria using Aloe Vera (Aloe barbadensis) extracts.
}

\author{
${ }^{* 1}$ AGWA, OK; IYALLA, D; ABU, GO \\ Department of Microbiology, Faculty of Science, University of Port Harcourt, \\ P.M.B. 5323, Rivers State, Nigeria \\ *Corresponding author: obioma.agwa@uniport.edu.ng
}

\begin{abstract}
The inhibition of biocorrosion of steel coupons by sulphate reducing bacteria (SRB) and Iron oxidizing bacteria (IOB) using Aloe vera (Aloe barbadensis) extract was tested. The water sample revealed a heterotrophic bacterial count of $1.7 \times 10^{3} \mathrm{cfu} / \mathrm{ml}$ for the sulphate reducing bacteria and $4.1 \times 10^{3} \mathrm{cfu} / \mathrm{ml}$ for the Iron oxidizing bacteria. Biocorrosion inhibition test using Aloe vera extract was prepared with $50 \% \mathrm{w} / \mathrm{v}$ stock solution at 10 $\%, 20 \%, 40 \%$ and $80 \%(\mathrm{v} / \mathrm{v})$ concentrations. An increase in acidity was observed in the fresh post gate medium after 7 days to 6.6 with a slight drop to 6.5 after 28 days in the setup with SRB. In contrast, the pH of the setups with IOB showed an increase in alkalinity from 6.8 in fresh Winogradsky medium to 7.4 after 7 days. The conductivity of SRB setup increased from $3150 \mu \mathrm{S} / \mathrm{cm}$ to $27100 \mu \mathrm{S} / \mathrm{cm}$ after 7 days and decreased to $200 \mu \mathrm{S} / \mathrm{cm}$ after 28 days. On the other hand, the IOB setup showed an increase in conductivity from $100 \mu \mathrm{S} / \mathrm{cm}$ to $2820 \mu \mathrm{S} / \mathrm{cm}$ after 28 days. The surfaces of the metal coupon used in the biocorrosion testing were slimy to touch, indicating possible biofilm production. The average corrosion rate from day 7 to day 28 for IOB and SRB are 6.606 mpy and 12.48 mpy respectively. The $80 \%$ v/v concentration of Aloe vera extract gave the highest inhibition efficiency, ranging from 89\%-100\% for IOB and $66 \%$ $100 \%$ for SRB. Aloe vera extract inhibited corrosion of steel coupons mediated by aerobic iron oxidizing bacteria and anaerobic sulphate reducing bacteria. (C) JASEM
\end{abstract}

https://dx.doi.org/10.4314/jasem.v21i5.7

Keywords: Aloe Vera extract, biocorrosion, metal coupons, oxidizing bacteria, reducing bacteria

Corrosion is metal deterioration due to diverse chemical attack by various interactions within the environment. It is a persistent challenge that is difficult to eliminate completely, but its prevention is easy and can be achievable. Corrosion occurs after disruption of the metal's protective barrier, followed by a variety of reactions. These reactions can be in form of change in metal properties, composition of the surface and the immediate environment. Certain chemicals act as either synthetic or natural inhibitors decreasing the metal's susceptibility to environmental degradation. There is an imminent need for the building of efficient corrosion inhibitors that are ecologically friendly (Abiola et al., 2007; Sharma et al., 2015). A number of natural products with known applicability as good corrosion inhibitors for metals have been investigated (Sangeetha et al., 2012; Ulaeto et al., 2012; Okafor et al., 2013; Singh et al., 2013; Gupta, 2014; Yamuna and Anthony 2014; Desai, 2015; Souza et al., 2015). The close relationship between microfouling and corrosion process has recently gained increasing recognition by engineers and microbiologist. Microbiologically influenced corrosion (MIC) is usually understood as the deterioration of metal which is promoted and enhanced by the effect of microorganism. The main factor in microbiologically influenced corrosion, apart from other requirements such as energy and carbon source, electron donor, electron acceptor and water are microorganisms (Javaherdashti, 2008). When a metal is exposed to water, the water-borne microorganisms colonize its surface forming biofilm through a series of steps (Marangoni et al., 2013). Problems which occur when the biolfilm builds up are termed biofouling (Zou, et al., 2004). Microbial fouling not only cause microbiologically influenced corrosion but may also lead to other severe consequences such as product contamination, reduction in transfer or mechanical blockage (kumar et al., 2011). Although metal corrosion can occur without microorganisms, microbial activities accelerate the reaction rate (Horn and Jones, 2002; Videla et al., 1998; Schaechter 2004; Romeo 2008; Simões et al. 2010). Many bacteria have been shown to be associated with the process of biocorrosion since 1960s. According to Beech (2004), sulphate reducing bacteria (SRB), Iron/manganese oxidizing bacteria, Iron reducing bacteria, sulphur oxidizing bacteria and bacteria which produce organic acids and slimes are the dominant types of microorganism involved in microbiologically influenced corrosion in terrestrial and aquatic habitats. These microbes are found in natural biofilm as they all contribute to the complex consortia of biofilm (Beech and Coutinho 2003). Among others, SRB is not only the first group of interest in biocorrosion study (Videla et al., 1991b) but has also been recognised as the most significant contributors to microbiologically influenced corrosion (Coetser and Cloete, 2005; Marangoni et al., 2013). This study was carried out to assess theinhibition of biocorrosion of steel coupon 
by sulphate reducing bacteria and Iron oxidizing bacteria using Aloe vera (Aloe barbadensis) extract.

\section{MATERIALS AND METHOD}

Preparation of steel Coupon Specimen; The steel bar used in this experiment was cut mechanically into strips of size $1.8 \mathrm{~cm} \times 1 \mathrm{~cm} \times 0.2 \mathrm{~cm}$, polished with fine grade emery papers, washed, sterilized in an autoclave and weighed using electronic balance. The sterilized metal coupons were wrapped in a sterile foil until they were used. The scrapings were collected and wrapped in a sterile foil for Atomic Absorption Spectrophotometer (AAS) analysis.

Preparation of Aloe Vera extract; The sample was pulverized with a victory grinder and soaked in $99 \%$ Ethanol for $24 \mathrm{~h}$. The extract was filtered into a clean dry pre-weighed beaker through cheese cloth. The residue in the cheese cloth was severally soaked and filtered until the colour of the extract showed no trace of active ingredient under examination. The extract was placed in Plus (II) Gallenkamp Oven maintained at $78^{0} \mathrm{C}$ to vaporize the solvent (Ethanol). The residue was reweighed in the balance and the residue weight was calculated.

Weight of Residue $=($ Weight of residue + Beaker $)-$ (Weight of Beaker)

Preparation of Stock solution The stock solution was prepared by weighing $8 \mathrm{~g}$ of the Aloe vera extract in $16 \mathrm{ml}$ of deionised water. This gave a concentration of $50 \% \mathrm{w} / \mathrm{v}$. From the stock solution, $10 \%, 20 \%, 40$ $\%$ and $80 \%$ v/v concentrations were made as follows: $0.5 \mathrm{mls}$ of the stock solution was added to 5 $\mathrm{mls}, 2.5 \mathrm{ml}, 1.25 \mathrm{ml}$, and $0.625 \mathrm{ml}$ of deionised water.

Isolation and identification of sulphate reducing and iron oxidizing bacteria: A sterile bottle was used to collect water samples were collected from Ikpokulu River in Borikiri, Port Harcourt metropolis, Rivers State, Nigeria at a depth which the pipelines were placed $(30 \mathrm{~cm})$. The sample was collected close to corroded badges which have been abandoned for a long time. A ten-fold serial dilution was carried out on the water samples up to $10^{-3}$. Enumeration of the sulphate reducing bacteria was carried out by culturing $0.1 \mathrm{ml}$ of the dilutions on postgate agar medium with the spread plate method and incubated in an anaerobic jar at $30^{\circ} \mathrm{C}$ for 14 days. Iron oxidizing bacteria were isolated by plating $0.1 \mathrm{ml}$ of the diluted samples on Winogradsky medium, with the spread plate technique and incubated anaerobically at $30^{\circ} \mathrm{C}$ for 7 days. Identification of isolates were carried out using pure cultures of distinct organisms on nutrient agar slant were subjected to confirmatory biochemical tests including Gram stain, spore stain, motility and IMVIC. The isolates were identified by comparing the biochemical comparing the biochemical characteristics of already described taxa (David and John, 1994).

Biocorrosion and inhibition testing against the bacteria using Aloe Vera extract; A loopful of discrete colonies of iron oxidizing bacteria was suspended in Winogradsky broth and Other Winogradsky broth solutions containing $10 \%, 20 \%$, $40 \%$ and $80 \%$ of Aleo vera extracts. Forty (40) preweighed metal coupons (steel coupon) labelled $\mathrm{I}_{1}-\mathrm{I}_{40}$ were placed into Bijou bottles containing the set ups in pairs. The set up were incubated aerobically at $30^{\circ} \mathrm{C}$. The coupons were withdrawn after 7 days, washed, dried and re-weighed. The procedure was repeated for a 7days interval three times (14, 21 and 28 days). A looful of sulphate reducing bacteria was suspended in fresh Postgate broth and another set up containing Postgate broth and $10 \%, 20 \%, 40 \%$ and $80 \%$ Aloe vera extract respectively. Forty (40) preweighed metal coupons (Steel coupons) labelled $\mathrm{S}_{1}$ $\mathrm{S}_{40}$ were placed in pairs inside Bijou bottles containing both set up and incubated anaerobically at $30^{\circ} \mathrm{C}$ for 7 days. The same procedure was repeated for a 7 day interval thrice $(14,21$ and 28 days). The controls for both Iron oxidizing bacteria and Sulphate reducing bacteria set up comprised uninoculated sterile media. The loss in weight of the metal coupons was calculated and the corrosion rates were calculated as according to Davis, (2000) as follows:

$$
R=K W / A T D
$$

Where; $\mathrm{K}=$ Constant equal to $3.45 \times 10^{6} ; \mathrm{W}=\mathrm{Weight}$ loss in gram; $A=$ Area to the nearest $0.01 \mathrm{~cm}^{2} ; \mathrm{T}=$ Time of exposure in hours; $\mathrm{D}=$ Density of metal (Steel) coupon; Inhibition efficiency (\%) was also determined by the following formula:

Inhibition efficiency $(\%)=\frac{C R_{B}-C R_{I}}{C R_{B}} X 100$

Where; $\mathrm{CR}_{\mathrm{B}}$ and $\mathrm{CR}_{\mathrm{I}}$ are corrosion rates in the absence and presence of inhibitor respectively.

Physicochemical analysis; Measurements of the ${ }_{\mathrm{P}} \mathrm{H}$ of the samples and experimental set ups were carried out using a ${ }_{\mathrm{p}} \mathrm{H}$ meter (model 5021). The instrument was standardized and the electrode dipped into the solutions whose ${ }_{\mathrm{P}} \mathrm{H}$ was to be determined. The steady displayed reading was the ${ }_{\mathrm{P}} \mathrm{H}$ of the sample solution. The conductivity of the experimental samples was measured by first flushing the electrode with distilled water to get a zero reading from the meter before 
dipping the electrode into the samples and the conductivity values recorded in Millisiemens per meter $(\mathrm{Ms} / \mathrm{m})$. The conductivity meter used was JENWAY model 4010. Atomic absorption spectrophotometry was used to analyze the $\mathrm{Fe}^{2+}$ of the set ups.

\section{RESULTS AND DISCUSSIONS}

The biocorrosion of Steel coupons by SRB and Iron oxidizing bacteria using Aloe vera extract as a green inhibitor of biocorrosion was evaluated. There are about seventy-five potentially active constituents including minerals, sugars and vitamins enzymes among others (Hart and James, 2014). They also contain monosaccharide and Anthraquinones which are phenolic compounds, some of which acts as antibacterial and antiviral compounds. These Anthraquinone compounds have been used to inhibit corrosion (Amitha and Bharathi, 2012). The Steel coupons contained Chromium, Copper, Zinc, and Iron with concentration $(\mathrm{mg} / \mathrm{kg})$ of $895.63,3989.00$, 8225.00 , and 344963.00 respectively with a density of $7.89 \mathrm{~g} / \mathrm{cm}^{3}$. The predominant composition of the Steel coupon is Iron, on which corrosion basically occurs most. An average Iron oxidizing bacterial count of $4.1 \times 10^{3} \mathrm{cfu} / \mathrm{ml}$ was obtained with an average sulphate reducing bacteria of $1.7 \times 10^{3} \mathrm{cfu} / \mathrm{ml}$ in the water sample. After the test period, a change in the physical appearance of the steel coupons was observed; the coupons placed in the Iron oxidizing bacterial culture were rusty and had a slimy surface, indicating biofilm formation, while the coupons subjected to the SRB culture appeared black indicating Iron sulphide deposition (Anichi and Abu, 2012). The average corrosion rate of the Steel coupons incubated in suspensions of Iron oxidizing bacteria in the absence of inhibitor (Aloe vera extract) was determined. The average corrosion rate after 7days was $1.103 \mathrm{mpy}$ and increased to $8.961 \mathrm{mpy}$ and $9.191 \mathrm{mpy}$ after 14days and 21days respectively. The corrosion rate however decreased to $7.169 \mathrm{mpy}$ after 28days, $11.51 \mathrm{mpy}$ after 21days and 28days respectively. The average corrosion rate of Steel

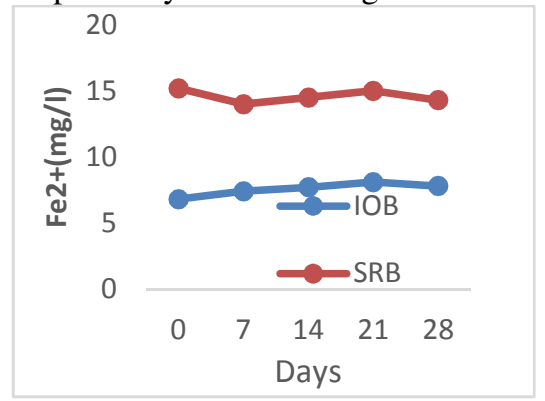

Fig 1: $\mathrm{pH}$ of suspension containing Iron oxidizing and sulphate reducing bacteria coupons in the presence of inhibitor (Aloe vera extract) at any concentration was shown to be lower than the average corrosion rate in the absence of inhibitor (Aloe vera extract) in solutions containing Sulphate reducing bacteria and Iron oxidizing bacteria. Previous study by Obuekwe et al. (1981) showed that mild steel was extensively pitted with a concurrent formation of sulphide and ferrous ions. Corrosion rate was shown to increase at the initial formation of sulphide, but was slowed by the subsequent formation of the ferrous protective film. The formations of soluble iron have prevented protective layer formation. The corrosion of the Steel coupon is mostly on the Iron component, which was observed in the high levels of soluble $\mathrm{Fe}^{2+}$ in the culture solutions of Iron oxidizing bacteria and Sulphate reducing bacteria respectively. Moulin et al. (1998) reported high corrosion rates attributed to high levels of soluble iron on carbon steel. $\mathrm{Fe}^{2+}$ availability have been reported to be regulated by hydrogenase formation of Desulfovibrio vulgaris giving an alternative mechanism affecting corrosion (Cheung and Beech, 1996). The composition of the Steel coupon showed the predominant metal to be Iron with a concentration of $344963.00 \mathrm{mg} / \mathrm{kg}$. The water sample had an initial $\mathrm{pH}$ of 6.1 , the Iron oxidizing bacteria increased from 6.8 in the freshly prepared solution to 7.8 after 28 days of incubation. A decrease resulted in Sulphate reducing bacteria from 8.4 in the freshly prepared solution to 6.5 after 28 days (Fig. 1). The production of hydrogen sulphide may be responsible for the acidity of the experimental set (Elke et al., 2000). The fresh Postgate medium $\mathrm{pH}$ with the SRB showed an increase in acidity from 8.4 to 6.6 after 7 days and dropped to 6.5 after 28 days. While, IOB showed an increase in alkalinity from 6.8 to 7.4 after 7 days, this drift can be attributed to formation of oxides and hydroxides of iron. On the other hand, there was a decrease in $\mathrm{pH}$ in the set up containing Sulphur reducing bacteria from 8.4 in the freshly prepared solution to 6.5 after 28 days.

The conductivity increased from $100 \mu \mathrm{S} / \mathrm{cm}$ to 3200 $\mu \mathrm{S} / \mathrm{cm}$ after 7 days and decreased to $2820 \mu \mathrm{S} / \mathrm{cm}$ after 28days with the Iron oxidizing bacteria. But for Sulphate reducing bacteria a drastic increase from $3150 \mu \mathrm{S} / \mathrm{cm}$ to $27100 \mu \mathrm{S} / \mathrm{cm}$ was observed but after 7 days, dropped to $7400 \mu \mathrm{S} / \mathrm{cm}, 700 \mu \mathrm{S} / \mathrm{cm}$ and $200 \mu \mathrm{S} / \mathrm{cm}$ after 14days, 21days and 28days respectively (Fig. 2). 


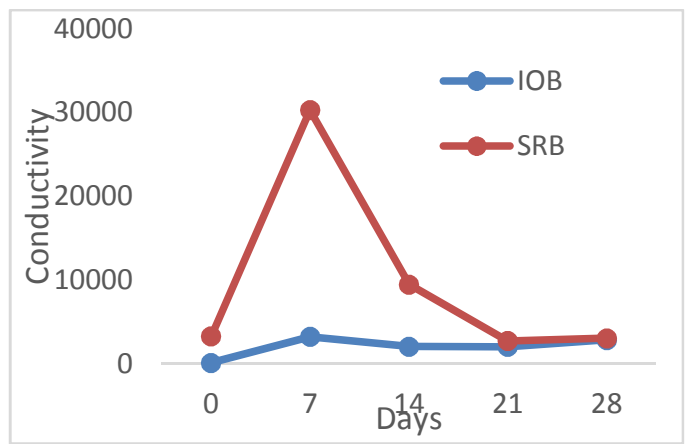

Fig 2: Conductivity $(\mu \mathrm{s} / \mathrm{cm})$ of suspension containing IOB \& SRB

This decrease may be attributed to the presence of bacteria genera such as Crenothrix Leptothrix, Sphaerotilus, Siderocapsa, Gallionella, and Clonothrix which are characteristically non-ionic resulting in the biotransformation of oxides of metals such as iron and manganese (Gounot, 1994). The conductivity of the set up containing sulphate reducing bacteria increased drastically from $3150 \mu \mathrm{S} / \mathrm{cm}$ to $27100 \mu \mathrm{S} / \mathrm{cm}$ after 7 days as a result of the hydrogen sulphide formation $\left(\mathrm{H}_{2} \mathrm{~S}\right)$ which is a weak acid. The increase in Iron (II) ions presence from Sulphate reducing bacteria and Iron oxidizing bacteria over a period of 28days is an indication of biocorrosion (Figs. 3). A study by Malik et al., (1992), showed a decreasing corrosion with a corresponding increase in $\mathrm{pH}$. Corrosion rate was also shown to increase with a linear increase of chloride. The corrosion rate of the Steel coupon in the absence of inhibitor was shown to increase within 21 days of incubation with increasing $\mathrm{pH}$ and decreased by $22 \%$ after 28 days with a drop in $\mathrm{pH}$ in the set up containing Iron oxidizing bacteria. On the other hand, the set up containing Sulphate reducing bacteria showed an increase in corrosion with decreasing $\mathrm{pH}$. The average corrosion rate of the Steel coupon in the absence of inhibitor (Aloe Vera extract) was shown to increase within 14 days with

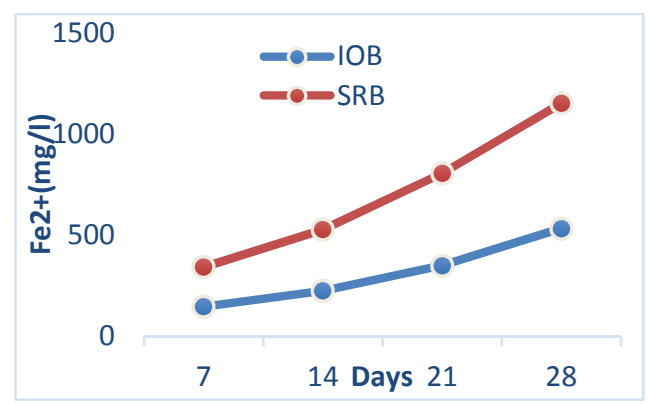

Fig 3: Iron (II) ion ( $\mathrm{mg} / \mathrm{l})$ of suspension containing Iron Oxidizing and Sulphur Reducing Bacteria

decreasing $\mathrm{pH}$. However, there was a decrease of $43 \%$ after 21 days and $51 \%$ after 28 days. There is a significant relationship conductivity and corrosion rate of the solutions containing the SRB and Iron oxidizing bacteria. As the conductivity of the solution containing the Iron oxidizing bacteria decrease from day 7 to day 21, the corrosion rate increased and at day 28 when the conductivity of the solution increased, the corrosion rate decreased. Steel coupon corrosion in the solution containing the Sulphate reducing bacteria was highest with a decrease in conductivity from day 7 to day 14 , and then decreases from day 14 to day 28. Also, as the concentration of Aloe Vera extract increases, the corrosion rate was shown to decrease in both solutions of the Sulphate reducing bacteria and Iron oxidizing bacteria (Fig. 4 and 5). A study by Zhang et al., (2003) showed that steel corrosion depends on the formation of dissolved oxygen, chloride ions, carbonate and calcium ions.

Some research groups have studied the use of naturally occurring substances to inhibit metal corrosion, with extracts of Delonix regia exhibiting aluminum corrosion in acidic solutions. (Abiola et al., 2007) 


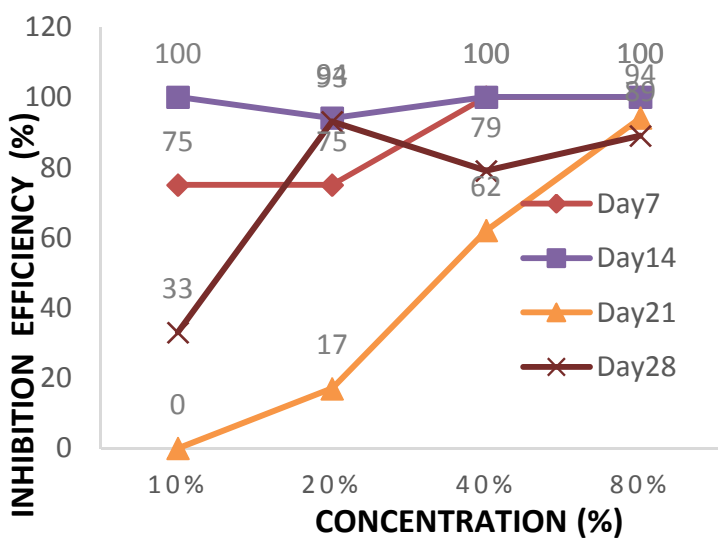

Fig 4.inhibition efficiency of aloe vera extract in suspension of iron oxidizing bacteria

A study by Eddy et al., (2009) showed variations in the temperature, concentration, immersion period, electrode potentials and $\mathrm{pH}$ in the adsorption of Musa sp on mild steel, which was spontaneous in line with the physical adsorption, and the Langmuir and Frumkin adsorption isotherms. The inhibition efficiency is shown to be affected by the concentration of the Aloe vera extract and the time of exposure in days. An increase in extract concentration resulted in an increase in inhibition efficiency. This is may be because the quantitative phytochemical analysis of Aloe vera extract during which the particular secondary metabolite responsible for biocorrosion inhibition of Steel coupons which could have been isolated and used precisely was not carried out. Hence, the optimum concentration of the active component of Aloe vera extract needed for biocorrosion inhibition was not determined.

Biofilm development by microbes that adhere to industrial surfaces has been shown to cause corrosion of metals, indicating that inhibition of biofilm production of surface bacteria is a simple way of decreasing and inhibiting corrosion.

Conclusion; The inhibition of corrosion by Aleo vera was observed in extract concentrations ranging from $10-80 \%$ $(\mathrm{v} / \mathrm{v})$. Aloe vera extracts, a green inhibitor, has the potential to inhibit biocorrosion and can be considered as an ecologically friendly approach for corrosion mitigation.

\section{REFERENCES}

Abiola, OK; Oforka, NC; Ebenzo, EE; Nwinuka, NM (2007). Eco-friendly corrosion inhibitors: The inhibitive action of Delonix Regia extract for the corrosion of aluminium in acidic media. Anticorrosion methods and materials. 54:219-224.

Amitha, BE; Bharathi BJ (2012). Green inhibitors for corrosion protection of metals and alloys. International Journal of corrosion. 15: 064-070.

Anichi, SE; Abu, GO (2012). Biodeterioration of pipeline concrete coatingmaterial by iron oxidizing and sulphate reducing bacteria (SRB). Journal of

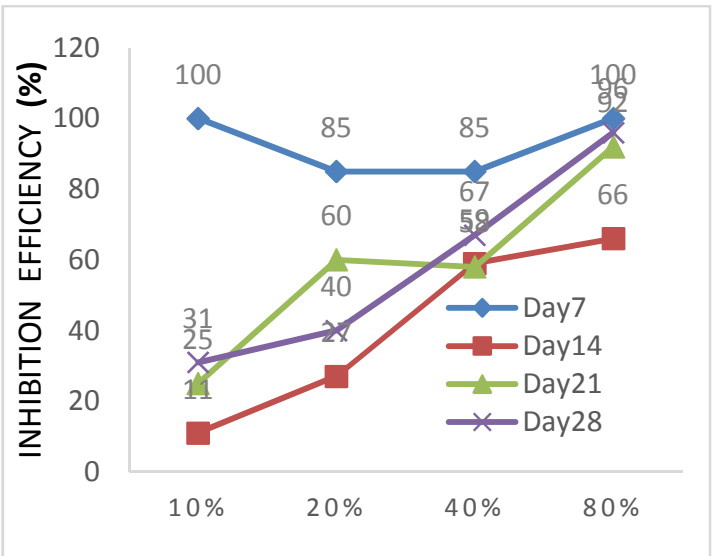

Fig. 5 Inhibition efficiency of Aloe vera extract in suspension of Sulphate reducing bacteria

Petroleum and Environmental Biotechnology. 3.114 doi: 4172/2157-7463.1000114.

Beech, IB (2004). Corrosion of technical material in the presence of biofilm-current understanding and state of the art methods of study. International Biodeterioration and Biodegradation. 53: 173-183.

Beech, IB; Coutinho, CL (2003). Microbial Biofilm on corroding materials; In Biofilm in medicine, Industry and Environmental Biotechnology-Characteristics, Analysis and Control ed. By Lens, P., Moran, A.P., Mahony, T., Stoodly, p., Oflaherty, V., IWA Publishing of Alliance House. p. 115-131.

Cheung, CWS; Beech, IB (1996). The use of biocides to control sulphate-reducing bacteria in biofilms on mild steel surfaces. Biofouling. 9: 231-249.

Coetser, SE; Cloete, TE (2005). Biofouling and Biocorrosion in Industrial Water systems. Critical Reviews in Microbiology. 31: 213-232.

David, HB; John, DH (1994). Berger's manual of determinative bacteriology. p. 335-340.

Davis, GD (2000). The Use of Extracts of Tobacco Plants as Corrosion Inhibitors, DACCO SCI, INC, Columbia, Md, USA.

Desai, PS (2015a) Hibiscus rosa-sinensis (Jasud) leaves extracts used as corrosion inhibitors for mild steel in hydrochloric acid. E-jpmr 2(1):470-485

Eddy, NO; Odoemelam, SA; Odiongenyi, AO (2009). Ethanol extract of musa species peels as a green corrosion inhibitor for mild steel: kinetics, adsorption and thermodynamic considerations, Electronic Journal of Environmental, Agricultural and Food Chemistry. 8: 243- 255. 
Elke, V; Verstichel, S; Monteny, J; Verstraete, W (2000). A new test procedure for biogenic sulphuric acid corrosion of concrete. Biodegradation 10:421-428.

Gounot, AM (1994). Microbial oxidation and reduction of manganese: Consequences in groundwater and applications. FEMS Microbiology Reviews. 14: 339350 .

Gupta, P; Jain, G (2014). Corrosion inhibition by Aloe barbadensis (aloe vera) extract as green inhibitor for mild steel in $\mathrm{HNO}_{3}$. IJSRR 3(4): 72-83.

Hart, K; James, AO (2014). The Inhibitive Effect of Aloe Vera Barbadensis Gel on Copper in Hydrochloric Acid Medium. Journal of Emerging Trends in Engineering and Applied Sciences (JETEAS) 5(1): 2429.

Horn, J; Jones, D (2002). Microbiologically Influenced Corrosion: Perspectives and approaches, Manual of Environmental microbiology, $2^{\text {nd }}$ ed., p. 1072-1083.

Javaherdashti, R (2008). Microbiologically Influenced Corrosion- An Engineering Insight, Engineering Materials and Processes (Engineering materials and processes), Springer.

Kumar, MA; Anandapandian, KTK; Parthiban, K (2011). Production and Characterization of Exopolysaccharides (EPS) from biofilm Forming Marine Bacterium. Braz. Arch. Biol. Tech. 54: 259265.

Malik, AU; Mayan, PC; Kutty Nadeem, A; Ismaeel, S; Adijanani, N; Shahreer A (1992). The influence of $\mathrm{pH}$ and chloride concentration on the corrosion behaviour of AISI 316L in aqueous solutions. Corrosion science, 33: 1809-1827.

Marangoni, PRD; Robl, D; Berton, MAC; Garcia, CM; Bozza, A; Mariana Vieira Porsani, MV; Dalzoto, PR; Vicente, VA; ${ }^{\text {II }}$; Ida Chapaval Pimentel,IC; (2013). Occurrence of sulphate reducing bacteria (SRB) associated with biocorrosion on metallic surfaces in a hydroelectric power station in Ibirama (SC) - Brazil. Braz. arch. biol. technol. 56:5

Moulin, JM; Marsh, E; Chao, V; Karius, R; Beech, IB; Gubner, R; Raharinaivo, A (1998). Prevention of Accelerated Low-Water Corrosion on Steel Piling Structures due to Microbiologically Influenced Corrosion Mechanisms; ECSC final draft report, ECSC agreement 7210-KB/503, KB/825, KB/130, $\mathrm{KB} / 826, \mathrm{~KB} / 337$.

Obuekwe, CO; Westlake, DWS; Plambeck, JA; Cook, FD (1981). Corrosion of mild steel in cultures of ferric iron reducing bacterium isolated from crude oil I. polarization characteristics. Corrosion Science 37: 461-467.
Okafor, PC; Ikpi, ME; Ekanem, UI; Ebenso, EE (2013). Effects of extracts from Nauclea latifolia on the dissolution of carbon steel in $\mathrm{H}_{2} \mathrm{SO}_{4}$ solutions. Intl. J. Electrochem. Sci. 8:12278-12286.

Sangeetha, M; Rajendran, S; Sathiyabama, J; Prabhakar, P (2012). Eco friendly extract of banana peel as corrosion inhibitor for carbon steel in sea water. $J$. Nat. Prod. Plant Resour. 2(5): 601-610.

Schaechter, M (2004).The Desk Encyclopedia of Microbiology. London, UK: Elsevier Academic Press.

Sharma, SK; Peter, A; Obot, IB (2015). Potential of Azadirachta indica as a green corrosion inhibitor against mild steel, aluminum, and tin: a review. Journal of Analytical Science and Technology 6: 26.

Simões, M; Simões, LC; Vieira, MJ (2010). A review of current and emergent biofilm control strategies. $L W T$ Food Sci Technol. 43: 573-583.

Singh, A; Kumar, A; Pramanik, T (2013). A theoretical approach to the study of some plant extracts as green corrosion inhibitor for mild steel in $\mathrm{HCl}$ solution. Oriental Journal of Chemistry 29(1): 277-283.

Souza, TF; Magalhães, M; Torres, VV; D'Elia, E (2015). Inhibitory action of Ilex paraguariensis extracts on the corrosion of carbon steel in $\mathrm{HCl}$ solution. Intl. J. Electrochem. Sci. 10:22-33

Ulaeto, SB; Ekpe, UJ; Chidiebere, MA; Oguzie, EE (2012) Corrosion inhibition of mild steel in hydrochloric acid by acid extracts of Eichhornia crassipes. Intl. J. of Materials and Chemistry 2(4):158-164.

Videla, HA; Herrera, LK (1991b). Microbiologically Influenced Corrosion: looking to The future. International Microbiology. 8: 169-180.

Videla, HA; Swords, CL; de Mele, M; Edyean, RG; Watkins, P; Beech, IB (1998). The role of iron in SRB-influenced corrosion of mild steel. Corrosion 98, NACE, Houston, Tx., Paper No 289.

Yamuna, J; Anthony, N (2014). Citrus sinensis L. leaf extract as an efficient green corrosion inhibitor for mild steel in aqueous medium. International Journal of Chem. Technol. Research 7(01):37-43.

Zhang, Z; Song, S; Haung, J; Ji, L; Wu, F (2003). Investigation of corrosion caused by constituents of refinery wastewater effluent used as circulating cooling water. Water research. 75: 61-65.

Zuo, R; Ornek, D; Syrett, BC; Green, RM; Hsu, CH; Mansfeld, FB; Wood, TK (2004). Inhibiting mild steel corrosion from sulphate-reducing bacteria using antimicrobial-producing biofilm in Three-Mile-Island process water, Appl. Microbiol. and Biotechnol.. 64: 275-283. 